\title{
Navigating Public Values
}

How the Social Construction of Technology among Public Managers Defines the Nature of Public Values: Findings from a Japanese e-Government Project

\section{Francesco Gualdi}

The London School of Economics and Political Science, f.gualdi@lse.ac.uk

Keisuke Idemitsu

Ministry of Economy, Trade and Industry, idemitsu1101@gmail.com

E-government literature has widely investigated how different understandings of technology impact on the trajectory of technologybased policies and projects. Yet, limited attention has been given to the effects that the social construction of technology has on the public values that public organizations aim to achieve through e-government projects. Building on technological frames theory, the paper aims to offer a contribution to public value literature: we show how different understandings of technology within public organizations define the nature of the public values related to policies and projects. The paper relies on the findings of a Japanese government web portal case to illustrate how the different frames of technology forced the public managers to rethink the organization strategy, and how this had an effect on the transformation and change of the public values the e-government project aimed to achieve.

CCS CONCEPTS • Applied computing $\rightarrow$ E-government; $\bullet$ Social and professional topics $\rightarrow$ Socio-technical systems; $\bullet$ Social and professional topics $\rightarrow$ Government Technology Policy

Additional Keywords and Phrases: E-government projects, datasets, technological frames, public values

\section{Introduction}

The outbreak of the coronavirus disease (COVID-19) has shown how important is the establishment of effective and efficient digital channels of communication between governments and citizens and enterprises [1]. In particular, the uncertainty related to COVID-19 complex and changing measures has increased the necessity for Small and Medium Enterprises (SMEs) to have access to qualitative, rapid and precise information in order to secure their businesses. As a consequence, the design of Government-to-Business (G2B) websites and portals became a paramount task for public sector managers $[\underline{2}, \underline{3}]$.

However, the process of creating a single e-government project, such as the launch of a public portal, can be extremely complex within large organizations which rely on many different actors to execute the project. Scholars have investigated how e-government projects drift away from original purposes and experience multiple changes of directions [ [4-6]. Among many, one key factor which impacts on the trajectory of e-government projects is the level of public managers' understanding and interpretation of the technology which underpins e-government projects [7]. Research has largely discussed how alignment or misalignment among public managers impact on the adoption of technological instruments [7].

The paper adopts the perspective of technological frames theory, as outlined by seminal work by Orlikowski and Gash [요, 9$]$ to show how public managers' social construction of technology influences the adoption of technological instruments within organizations. The paper builds on this stream of literature to develop its case. First, it sheds a light on how different framings of technology impact on the trajectory of technology adopted in public organizations [10]. Second, it accounts for how the technological frames impact on the direction of e-government projects [11]. However, the paper aims to make a step further: it shows how technological frames inform the public value creation in e-government projects. The paper contributes to the public value literature by accounting for the way by which public managers' aligned or misaligned technological frames produces multiple shifts and transformations on the nature of the public values. To build our case, we aim to address the following Research Question: what is the impact of public managers' technological frames on the nature of the public values inscribed into e-government projects?

In order to demonstrate our thesis, we analyze the case of a G2B project in the Japanese Ministry of Economy, Trade and Industry (METI) which is based on the design of a governmental web portal providing information to SMEs.

The paper is structured as follows. Section two accounts for the relevant literature in the field of e-government related to public values. Section three describes the key elements which constitute the theory of technological frames, and it explains why this theory is appropriate for this case. Section four clarifies elements of the methodology utilized in the research. Section five introduces the case of the Japanese e-government project. Section six discusses the main findings from the case. Section seven offers the conclusions of the research.

\section{Literature background}

The concept of public value originates in the seminal work by Moore $[\underline{12}, \underline{13}]$. Moore focuses on the main task of public managers, which is to create public value within the boundaries of legitimation, political sustainability, and organization's capabilities and resources [14]. Public value perspective offered an answer to both Weberian bureaucracy and New Public Management (NPM) approaches, emphasizing the role played by collective preferences over individual preferences in the public sector projects design. Although there is not a shared consensus on the definition of public value [15], literature has refined the concept and it has offered many interpretations of what public value is. Scholars who have adopted public value perspective emphasize that the citizens who are subject to the policies do not simply carry individual, self-maximizing interests: rather, they value public sector outcomes on the 
basis of different elements such as social, political, democratic principles [15]. As a consequence, public managers in charge to deliver public sector outcomes need to take into account the relevance of citizens' collective expectations and beliefs.

Building on these findings, e-government literature has utilized public value perspective to analyze technological adoption in the public sector. While the original elaboration by Moore [13] didn't include any reference to technology, subsequent scholars outlined different understanding of public value in relation to information systems deployed in public administration [15-17].

Hence, e-government literature has increasingly adopted the public value perspective to account for the way by which technology impacts in public sector reforms and policies [15]. The public value perspective offers key instruments to challenge the idea that technology carries only straightforward effects on the public sector policies which it underpins $[16, \underline{18}, \underline{19}]$. With the public value perspective, it is possible to provide a more precise account of all the nuanced outcomes which emerge after the Information and Communication Technology (ICT) adoption in the public sector. Building on this viewpoint, scholars advanced the idea that instead of value, the attention should focus on values, to capture the nuances which characterize the multidimensional impacts of public sector ICT-mediated reforms [프, 20, 21] .

Relevant streams of research in the field of e-government have addressed fundamental goals such as how to classify public values $[17, \underline{19}]$ and how to measure public values $[22,23]$. Although valuable, these works take an institutional perspective to public values, which focuses on what public values are $[\underline{21}, \underline{24}]$ : this literature does not look into the very specific changes and transformations of values that happen when an e-government project is designed, drafted, discussed and implemented.

Yet, as other scholars have pointed out, research should not investigate the process by which public values are inscribed into ICTbased public sector projects only in advance (ex-ante) or in retrospect (ex-post) [4]. Rather, along the process of e-government policy design, there is the need for an evaluation of public values trajectory which considers exchanges, assessments, new expectations and beliefs. Scholars described this approach to the study of public values as generative [21] or iterative [4]. This approach concentrates on what public managers might do to achieve public values in "increasingly uncertain, unstable environments" [24]. Within this approach, public values become normative concepts: public managers rely on them to shape the trajectory of policies and projects [25].

Hence, to account for the transformations and changes that inform the nature of public values of an e-government project, it is necessary to enhance and further investigate the key role of public managers. We acknowledge that research has focused on the increasing contribution of actors outside the public sector in the production of public value [26, 27]. However, against this background, we do not consider this transformation as a downgrade of public managers' role. On the contrary, their functions need to be recalibrated to encompass a panoply of different inputs which emerge [26]. This research joins the efforts of recent works which call for a renewed attention on public managers' understanding of technology when public ICT projects are deployed in the public sector [11]. A proper account of how public managers understand, and interact with, technology, is paramount to explain why they take specific decisions which modify the course of e-government projects and how these decisions influence the public values that the projects aim to achieve. The paper relies on the theory of technological frames to disentangle the way by which public managers impact on the nature of public values inscribed into an e-government project.

\section{Theoretical framework}

\subsection{Technological frames}

The seminal work by Orlikowski and Gash [] ] on technological frames has shed a light on the way by which the different social constructions of technology of actors influence the trajectory of technological adoptions in organizations. The key concept Orlikowski and Gash outline is "technological frames", which they describe as "the subset of members' organizational frames that concern the assumptions, expectations, and knowledge they use to understand technology in organizations" [ㅁ] $]$. Within complex organizations, actors utilize frames to make sense of the context they belong to. As a consequence, when actors face the adoption of technological instruments and systems, the way they understand technology informs the interactions they have with it [요, 28]. Technological frames play a key role in the way by which organizations adopt technologies. As noted by Kaplan and Tripsas [10], technological frames do not impact directly the single technology, rather they allow the social construction of interpretative processes which help the actors to take decisions and actions following their own interpretation. This interpretative process connects technological frames to technological outcomes [10]. Hence, the salience of technological frames is relevant because researchers have focused on the way by which managers within organizations make sense of technology, and how this impacts on the trajectory of technology-based projects $[\underline{10}, \underline{11}, \underline{29}-\underline{31}]$.

Technological frames are useful lenses to investigate how public managers make sense of technology and how this affects the decisions related to ICT-based projects. Different technological frames from different actors produce changes in the ICT-based policies. These changes involve new directions, programme variations and the rethinking of aims and purposes of the projects $[10$, 11]. Leonardi has investigated how the managers' framing of technology produces impacts at different stages of the development of projects [르]. This dynamic perspective allows to better understand why there are tensions, clashes and divergences which might jeopardize the final outcome of the process [32].

In line with this stream of literature, we aim to utilize technological frames theory to better account for how aligned or misaligned technological frames among public managers influence their interaction with technology [ 8$]$, and thus how they inform the trajectory of e-government projects [33]. Moreover, this research aims to make a step further and to contribute to public value literature. The paper illustrates that the way by which public managers frame technology impacts not only on the e-government project but specifically on the nature of the public values that the e-government project aims to achieve. Technological frames can explain why conflicts and tensions about public values emerge [25] and how the different social construction and interaction about technology redefines expected public values at each stage of an e-government project $[\underline{11}, \underline{34}]$. 


\subsection{How to identify public values}

To assess how public managers' framing of technology impacts on the nature of public values, we need to clarify how the identification of public values will be conducted in this research. In this regard, e-government literature has provided many approaches to identify specific objectives included in public values. Van Wart shows that there are five value sources in public administration decision-making focusing on actors: individual's values; professional values; organizational values; legal values; and public interest values [ $\underline{35}]$. Another approach emphasizes the origins of values. For example, Bannister and Connolly propose a taxonomy of public values for assessing the impact of ICT, which consists of duty-oriented, service-oriented, and social-oriented values [19]. Subsequently, Twizeyimana and Andersson identify three dimensions and six values [17]. They adopt Ndou's egovernment framework [36], which consists of (1) transformation areas, (2) users, stakeholders and their interrelationships, and (3) egovernment application domains. Twizeyimana and Andersson investigate public values on the basis of these three components and find that there are dependencies between three dimensions [17]. The first dimension, improved public services, influences the other two dimensions. That is, these three dimensions, as well as the six values, overlap each other as Twizeyimana and Andersson [17] explain in their article.

Table 1. The taxonomy of public values in Twizeyimana \& Andersson (2019)

\begin{tabular}{|l|l|}
\hline Three dimensions & Six values \\
\hline 1) Improved Public Services & 1) Improved public services \\
\hline 2) Improved Administration & 2) Improved administrative efficiency \\
& 3) Open Government (OG) capabilities \\
& 4) Improved ethical behaviour and professionalism \\
\hline 3) Improved Social Value & 5) Improved trust and confidence in government \\
& 6) Improved social value and well-being \\
\hline
\end{tabular}

The paper relies on Twizeyimana and Andersson's taxonomy because it offers a comprehensive classification of values. Besides, these values can be easily clustered and re-conducted under a few dimensions, which simplifies the analysis throughout the research. An additional and relevant reason to adopt Twizeyimana and Andersson's taxonomy is that their research targets public values linked to e-government projects worldwide. This choice allows us to analyze the public value creation with a framework that does not focus only on European or American public administrations. This fact is relevant since the case study examined in this paper addresses an e-government project developed within the Japanese public administration.

\section{Methodology}

The paper analyses an e-government project of the Japanese government. The project aimed at providing information on supporting measures for SMEs through the establishment of a web portal named "Mira-Sapo Plus". The design of the project took place in the Ministry of Economy, Trade and Industry (METI) and the Small and Medium Enterprise Agency (SMEA), the latter being one of METI's external agencies within the Japanese government. The name "Mira-Sapo" means the contraction of "supporting future" in Japanese, and "Plus" means the second version of the service. This case was selected because it is the only official web portal of Ministries in the Japanese government that provides information on supporting measures for SMEs. While there are other web portals operated by government-related agencies and local governments, the first version of the web portal ("Mira-Sapo") represented the first web portal for SMEs in Japan; SMEA aimed at 1 million members and more than 200,000 accesses per week by the end of 2015.

This research adopts a qualitative case study approach [37, $\underline{38]}$ because it is suitable (a) to examine interactions between actors and the context behind them and (b) to explore a present phenomenon in its natural setting [39].

The data collection consists of documentation review and interviews. First, about the documentation review, we reviewed press releases on the websites of METI and SMEA, user manuals of "Mira-Sapo Plus", explanatory materials at meetings in METI and Cabinet Secretariat, and bidding specifications of SMEA. The authors also examined several websites of consultants where they explain how to use "Mira-Sapo Plus" for SMEs. Second, six online interviews with five staffs in METI and SMEA were conducted via video conference software for 50 to 90 minutes during five months starting in January 2020, as Table 2 shows. Interview sample questions ${ }^{1}$ were developed in order to investigate how managers contributed to the creation of public values. One of the authors conducted a semi-structured interview in which the questions were flexibly changed according to the answers during the interview. Snowball sampling was adopted after approaching the first informant. The authors interviewed twice the key informant, the first interviewee, to understand the situation in-depth. Interviews were conducted in Japanese and translated and quoted in English. Collected data processing happened in two ways: (1) organized to exhibit the timeline (as Table 3 shows), and (2) coded by public values as explained in section three. 
Table 2. The list of interviewees

\begin{tabular}{|c|c|c|c|}
\hline Interviews & Position in MET/SMEA & Period & Date and Duration \\
\hline$\# 1, \mathrm{~A}$ & $\begin{array}{l}\text { Deputy Director, IT Project Office (IPO) } \\
\text { Member of METI DX Office }\end{array}$ & $\begin{array}{l}\text { July } 2017 \text { - Current } \\
\text { August } 2018 \text { - Current }\end{array}$ & $\begin{array}{l}\text { 21st January } 2020 \\
\text { ( } 60 \text { minutes) } \\
\text { 25th March } 2020 \\
\text { ( } 75 \text { minutes) }\end{array}$ \\
\hline$\# 2, \mathrm{~B}$ & $\begin{array}{l}\text { Deputy Director, IPO } \\
\text { Deputy Director, Policy Planning and } \\
\text { Coordination Division (PPCD), SMEA }\end{array}$ & $\begin{array}{l}\text { Summer } 2016 \text { - July } 2017 \\
\text { July } 2017 \text { - July } 2018\end{array}$ & $\begin{array}{l}15 \text { th May } 2020 \\
\text { (50 minutes) }\end{array}$ \\
\hline$\# 3, \mathrm{C}$ & $\begin{array}{l}\text { Digitalization Promotion Manager, IPO } \\
\text { Member of METI DX Office and SMEA } \\
\text { DX Office }\end{array}$ & $\begin{array}{l}\text { June } 2018 \text { - Current } \\
\text { August } 2018 \text { - Current }\end{array}$ & $\begin{array}{l}\text { 20th May } 2020 \\
\text { ( } 60 \text { minutes) }\end{array}$ \\
\hline$\# 4, \mathrm{D}$ & $\begin{array}{l}\text { Unit Chief, Finance Division, SMEA } \\
\text { Member of SMEA DX Office }\end{array}$ & $\begin{array}{l}\text { June } 2016 \text { - March } 2019 \\
\text { August } 2018 \text { - March } 2019 \\
\end{array}$ & $\begin{array}{l}27 \text { th May } 2020 \\
\text { ( } 60 \text { minutes) }\end{array}$ \\
\hline$\# 5, \mathrm{E}$ & $\begin{array}{l}\text { Deputy Director, PPCD, SMEA } \\
\text { Member of SMEA DX Office }\end{array}$ & $\begin{array}{l}\text { June } 2018 \text { - August } 2019 \\
\text { August } 2018 \text { - August } 2019\end{array}$ & $\begin{array}{l}\text { 3rd June } 2020 \\
\text { (90 minutes) }\end{array}$ \\
\hline
\end{tabular}

\section{Case Description}

In recent years, Japanese SMEs have experienced several problems to find out information about the support measures they might access [40]. In some cases, the lack of available information has even prevented SMEs to access the measures [40]. In an effort to provide easy-to-understand support information for SMEs, the Japanese government first launched the web portal "Mira-Sapo" in July 2013 [41]. According to the interviews, the then Minister for Economy, Trade and Industry gave impetus to the launch of a web portal to unify a group of websites providing support information for SMEs, which had been scattered at that time. Despite the increasing number of new support measures, the Japanese government did not organize properly the information provision. The upload of updated information by SMEA on the "Mira-Sapo" web portal had been minimized. One public manager (Interviewee \#3) testified that it was not even clear who was responsible for the updates occurring in 2017. This happened because each single department was responsible for the support measures listed, regardless that Public Relations Departments in SMEA managed "MiraSapo". From the standpoint of each department, it was more convenient to update their own policies at their own time on their own website in their own way (Interviewee \#4 in Finance Division).

In this context, it is useful to understand how the project evolved as a consequence of different changes and transformations. $\underline{\text { Table } 3}$ offers a timeline of the project.

Table 3. The timeline and evolutions of the project

\begin{tabular}{|l|l|}
\hline Time & Events \\
\hline Phase 1: The Start of the Project & $\begin{array}{l}\text { The Budget and Accounts Division (BAD) instructed B (Interviewee \#2) in the } \\
\text { IT Project Office (IPO) to centrally manage the websites operated by various } \\
\text { sections in METI for efficient budget execution. }\end{array}$ \\
\hline June 2017 & $\begin{array}{l}\text { A (Interviewee \#1) succeeded B and consulted with B, who moved to the Policy } \\
\text { Planning and Coordination Division (PPCD), SMEA. B recognized the necessity } \\
\text { of the integration of websites in SMEA. }\end{array}$ \\
\hline Summer to Winter 2017 & $\begin{array}{l}\text { B attempted to standardize the data format in several divisions in SMEA with A } \\
\text { and IPO staff, but B complained to A of lack of support by IPO. }\end{array}$ \\
\hline Phring 2018 & $\begin{array}{l}\text { A decided to hire a specialist for the project. } \\
\text { A suggested to B to hold a proposal type contest in order to involve motivated } \\
\text { members in SMEA. }\end{array}$ \\
\hline June 2018 & $\begin{array}{l}\text { C (Interviewee \#3) was hired by IPO as a project manager for SMEA. } \\
\text { IPO (A and C) conducted some workshops and gathered staff interested in the } \\
\text { project (including D (Interviewee \#4) in Finance Division). }\end{array}$ \\
\hline
\end{tabular}




\begin{tabular}{|l|l|}
\hline August 2018 & $\begin{array}{l}\text { SMEA Digital Transformation (DX) Office was established, and C, D and E } \\
\text { (Interviewee \#5 who succeeded B) became members. }\end{array}$ \\
$\begin{array}{l}\text { Three projects were started based on the ideas at the workshops (D led the } \\
\text { "Support system navigation" project, and E led the "Case navigation" and } \\
\text { "Mira-Sapo revision" project). }\end{array}$ \\
\hline Phase 3: The Integration of Projects & $\begin{array}{l}\text { E recognized the inconsistency between the deliverables of the three projects } \\
\text { and decided to integrate them as a single web portal. }\end{array}$ \\
\hline March 2019 & C coordinated between the stakeholders and unified the website interface. \\
\hline April 2019 & The web portal "Mira-Sapo Plus" was released. \\
\hline
\end{tabular}

\subsection{Phase 1: Start of the Project}

As a response to the fragmented provision of key information to SMEs, METI's public management aimed to overcome the different and siloed sources of information by launching the construction of a single repository for the information to be released by the Ministry.

The deputy director of the IT Project Office (IPO) (B, Interviewee \#2) was put in charge of this initiative, with the fundamental aim to review the process which led to the realization of the web portal. In July 2017, A (Interviewee \#1) succeeded the deputy director of IPO and started to select the target projects to include in the web portal within the Ministry. In this phase, public managers such as A and B (who subsequently moved to the deputy director position in the Policy Planning and Coordination Division (PPCD), SMEA) aligned towards the goal. Both A and B shared the belief that METI was not properly providing information to SMEs due to duplicate websites and complicated interfaces. As a consequence, B started hearings to become aware of the different understandings of the technology at stake - website providing information - across different divisions of the SMEA.

Through these hearings, B determined that different actors in different divisions of SMEA carried out specific projects according to contrasting understandings of the relevance of technology. Hence, he became aware of the inefficiency and ineffectiveness of the projects.

As a coordination task of PPCD, we had interviews with SMEA staffs in each division. At that time, we found that each division provided similar information for SMEs in different ways. [Not only IPO but also] PPCD recognized that instead of each division proceeding in its own way, SMEA should establish a one-stop artefact with an integrated budget and user interface. [B, Interviewee \#2]

It is relevant that $\mathrm{B}$, as he mentioned, did not understand the inconsistency between the information provision websites at first. Yet, he recognized the problem after the budget hearing. Accordingly, he thought that those projects should be carried out in a prioritized manner with a unified principle. B tried to promote the standardization of the data format in each division with IPO members. However, B recognized two problems in the project: 1) the lack of support from the Executive Advisor for Chief Information Officer (EA-CIO), who was in charge of every project in METI and was not able to provide enough support for individual projects and 2) an insufficient commitment from each division. B requested A for further support.

\subsection{Phase 2: The Establishment of DX Office}

As a consequence of the exchange held with B, A analyzed the situation of the project in SMEA. He found that on top of the lack of support from the IPO, there was an additional problem: the existing staffs in each division were reluctant to review the data format. Different divisions carried their own single perspective and sense-making about datasets use and potential applications. Hence, this siloed approach was hindering the implementation of a single strategy to provide information to SMEs. Not only the Ministry was unable to deliver the expected outcome of information provision in a rationalized and efficient way. In addition, the different ways by which separate divisions managed datasets generated problems within the Japanese Ministry itself. Public managers holding competing and contrasting views of the same type of technology limited the potential of the whole structure.

Public managers acknowledged that to overcome the problems experienced, they had to better exploit the internal resources and the existing knowledge. Public manager A took two key decisions: first, he hired a Digitization Promotion Manager, C, and second, he encouraged cross-cutting collaboration among volunteers from different divisions, with the purpose of collecting ideas for new prototypes of useful applications for SMEs. The first decision aimed to strengthen the internal IT capabilities rather than outsourcing an ICT-based project. The second decision aimed to involve motivated members of SMEA to meet, discuss and come up with shared ideas on how to improve the data provision services of the Ministry. This strategy had the purpose to avoid the process of assigning reluctant members to key divisions. Public managers perceived workshops as the instrument by which to increase technological alignment across members of different divisions.

As the interview below shows, B agreed with the concept, he persuaded the managers of SMEA with A, and finally succeeded in establishing the SMEA DX Office.

The idea of IPO (A) caused a change in thinking [of project management]. The idea was to create a prototype that looks useful, and then use it to convince [staffs in SMEA]. Specifically, we decided to develop an app based 
on the ideas proposed in the contest. It was platform-minded thinking that would take over users (SMEs) and divisions in SMEA. [B, Interviewee \#2]

In July 2018, there was a project to create an app for SMEs: we gathered interested staffs from each division. At first, I participated as a voluntary work across the organization. I didn't think it was the official work of the Finance Division because the Finance Division was too busy and against the project at that time. However, there was a personnel exchange, and the new director decided to commit to the project at the timing when the SMEA DX Office was established. [D, Interviewee \#4]

As the two interviewees remarked, the recognition of the existing siloed approaches to dataset implementation shed a light on a further dimension of the whole project. Public managers realized that separated divisions used to stick with their own understanding of technological instruments - in this case, how to collect and handle datasets to release key information. This fact was preventing the whole organization from a better exploitation of internal resources. Beyond the original purpose of the project, which was to release in a better and more efficient way information to SMEs, public managers understood that with such a fragmented approach to technology, organizational capabilities could be wasted.

Until now, all IT service development in government has been outsourced; however, this has not left the knowhow of IT service development inside the organization. Hiring IT managers would contribute to accumulating technical knowledge within the government. Even if the development itself is outsourced, IT managers dramatically improve the communication with external IT vendors. [A, Interviewee \#1]

The involvement of motivated staff also contributed to the capabilities of systems development because they were digital natives as A mentioned in the interview below.

Young people are digital natives and they have an advantage in IT literacy. It is important to create an environment in which highly motivated staff can work comfortably. One way to do this is to create an organization. By setting up the organization properly, young people can work as their own business. [A, Interviewee \#1]

Based on the ideas provided by participants in the workshops, three sub-projects were selected to be developed: "Support system navigation" (an application for providing support measures such as subsidies to SMEs in an easy-to-understand manner, led by D); "Case navigation" (an application for sharing concrete best practices for management improvement, and "Revision of Mira-Sapo web portal” (aimed at reviewing the function of Mira-Sapo), both led by E.

\subsection{Phase 3: The Integration of the Project}

At this phase, public managers had introduced changes in the Ministry digital strategy governance, through the establishment of the DX Office, and they had encouraged officials to engage in new activities - namely, the workshops which produced three significant sub-projects.

Public managers realized that while the workshops produced meaningful outcomes, the emergence of three distinct subprojects could create additional challenges. E, who was in charge of the whole project as well as the project leader of the "Revision of Mira-Sapo" and the "Case navigation," problematized the disentanglement of three projects:

At first, we did not consider integrating the projects, but when we considered what to do with the "Mira-Sapo", we came to the conclusion that the portal site should be the gateway to all information. [E, Interviewee \#5]

D, who was in charge of the "Support system navigation" project, reflected on the situation at that time as below.

PPCD was in charge of "Mira-Sapo", and the "Support system navigation" and the "Case navigation" projects were conducted separately. There were not many meetings across three projects. In the first place, we didn't decide how to connect the three projects. The only thing we had decided to do was to build apps for SMEs with an agile method. [D, Interviewee \#4]

E considered that the solution was to unify the interface in order to improve the linkage between the projects. E involved D, who was leading the "Support system navigation" project and C, who supported three projects as a specialist. Since C happened to be an expert on all three projects, he adopted the approach of integrating the interfaces as a concrete solution to the problems raised by $\mathrm{E}$.

Because the progress of prototype development in each project was different, it was not possible to integrate all of them, so we combined the policy navigation and the case navigation separately from "Mira-Sapo". I managed each project and appointed an external design consultant to design the user interface in a unified way. [C, Interviewee \#3]

At this point of the project, public managers realized that the apps represented valuable contributions, but their use needed to be rationalized and improved in terms of usability. As showed, E acknowledged this problem and pointed out that user experience and user interface had to become priorities in the design of the new web portal. 
The "Mira-Sapo" was just hard to see. The reason was that the content was unorganized and scattered. I didn't understand how to see the webpage. There were so many banners, so many links, I didn't know what to look for and how to find them. [E, Interviewee \#5]

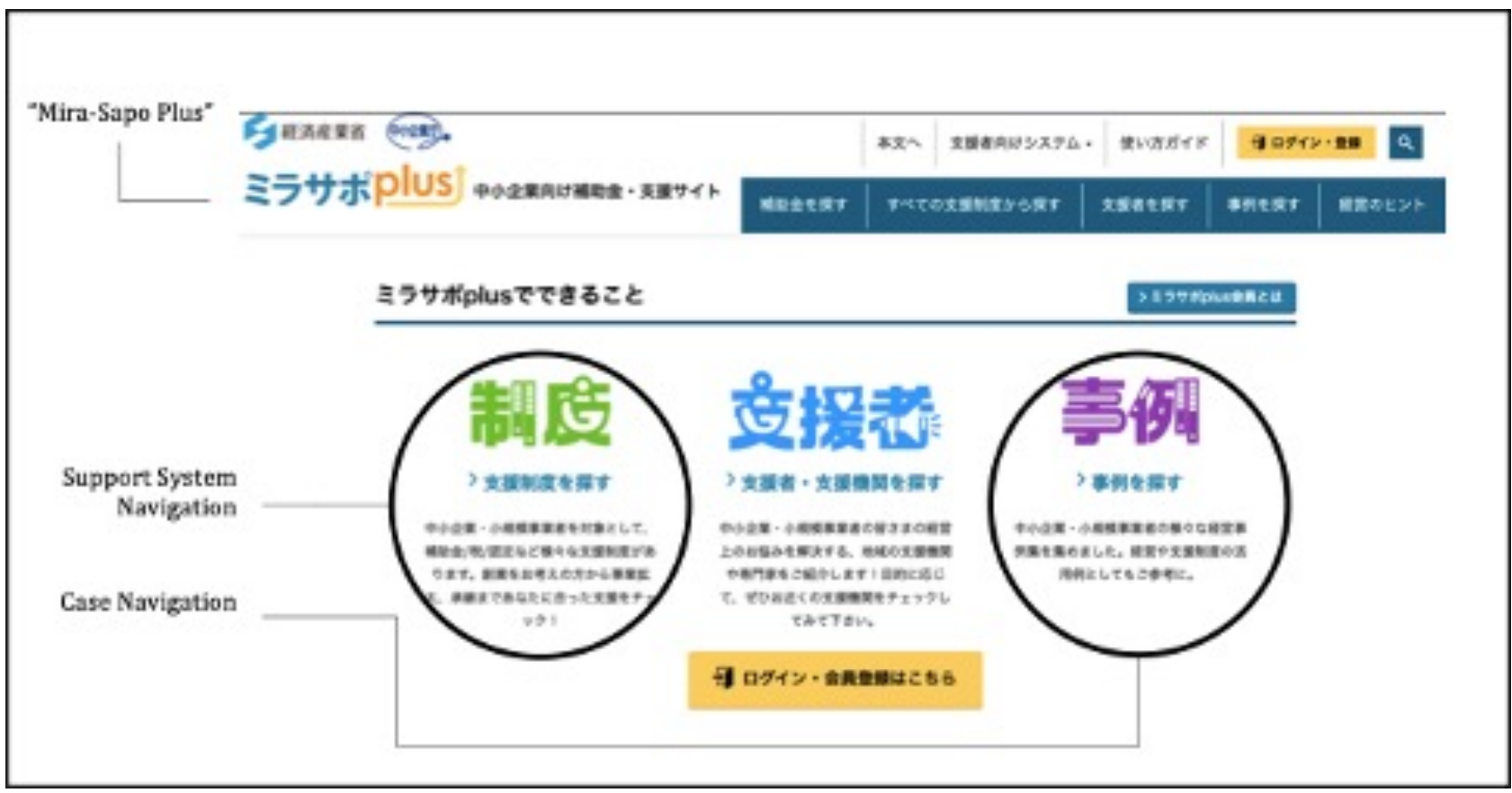

Figure 1. The interface of the "Mira-Sapo Plus" web portal (SMEA, METI 2020)

\section{Analysis}

The unfolding of the project over the years shows the multiple interactions among public managers in charge of the execution of the project, and how their framing of technology impacted over the trajectory of the technological adoption. It is worth recalling that the original purpose of the project was to realize a reliable source of information for SMEs by the Japanese Ministry. However, as the interviews of the key public managers show, several obstacles and changes of directions emerged as a consequence of the different technological frames. In this section, we are going to examine: (a) which public values were inscribed into the actions and activities related to the realization of the project - according to the taxonomy by Twizeyimana and Andersson [17]; (b) which technological frames emerged in the course of the project; (c) how the technological frames impacted on the technological trajectory; and (d) in which way the technological frames impacted the nature of public values.

\subsection{Phase 1: Start of the Project}

In the first phase - the start of the project - Japanese Ministry's public management was disappointed about the information provision to SMEs. Public manager B was asked to conduct a proper hearing to investigate the factors which were hindering the expected outcome. The public managers pursued the goal of a rationalization of the resources deployed and an improvement of the efficiency of the organization workflow. Besides the original value of improving the public service provision, public managers' actions concentrated on the key value of improving administrative efficiency. These two public values belong to two different dimensions: one dimension focuses outwards (the provision of a better public service) and the other focuses inwards (the improvement of the internal administration through a proper rationalization of the organizational resources and workflows).

According to the data collected, technological frames among public managers represented a source of misalignment and misunderstanding about the handling of datasets. Different divisions within the same public organizations held competing visions about how to exploit e-government instruments such as web portals to provide information. The Ministry was not able to offer rational instruments to service recipients (the SMEs): this fact jeopardized the efforts to provide a meaningful public service. The different and contrasting understandings about the use of datasets put at risk the organization's capabilities to execute administrative tasks in a proper way. The different, competing, and in some cases also colliding, views on the use of datasets held by separate divisions created dysfunctional technological adoptions within the same organization. This had an impact on the development of the technological trajectory, as confirmed by public manager B. These contrasting technological frames impacted also on the expected public values that the organization aimed to achieve through the use of technology. Due to these misalignments, the Ministry was not able to offer qualitative public service. Moreover, METI public management had to undertake actions in order to rationalize the internal workflows and, accordingly, the organization's administrative efficiency. 


\subsection{Phase 2: Establishment of DX Office}

The acknowledgement of the ongoing situation by public managers A and B - after the hearings - was a relevant step to adjust the trajectory of the project. First of all, A and B shared common awareness about the issues to fix, which contributed to a much clearer definition of the direction of the project. A and B realized that the competing technological frames not only put at risk the effectiveness of the web portal project. Rather, they realized that the way by which different divisions made sense and enabled technology was a key factor to undermine the internal capacity to adopt technological measures.

Public managers A and B decided to undertake actions with a different purpose: they wanted to strengthen the Ministry's technological capabilities. They substantiated this decision through the hiring of a professional from the private sector and through the workshops for volunteers across different divisions. These actions had a two-fold purpose. First, public managers aimed to create better internal knowledge about technological issues. Second, they wanted to overcome fragmentation by creating a group of officials aligned with a similar social construction of technology. Together, these actions aimed to increase the technological awareness of the whole organization. This had the purpose to lay the ground for smoother management of technological issues and to avoid the frequent recourse to outsourcing practices.

In terms of how the technological frames impacted the values, we can see that from a situation of extreme divergence and fragmentation, the research for a more aligned technological understanding pushed public managers to pursue values of Open Government capabilities and to improve the overall professionalism of Ministry's officials. As many interviewees admitted, they found that the workshops provided useful opportunities to better align towards a shared social construction of technology. Beforehand, this was not possible due to contrasting technological frames among separate divisions. These actions impacted on the trajectory of the technological adoption. Public managers overcame contrasting views on how to provide information, and they made additional steps forward towards the definition of an effective web portal. This process of aligning competencies and awareness produced a further benefit to the whole organization, which culminated in the creation of the DX Office. Public managers believed that DX Office could represent the place where different officials from separate divisions could construct a shared framing of technology. This could provide a decisive boost to achieve a common understanding and sense-making of technological solutions.

\subsection{Phase 3: Integration of the sub-projects}

After the establishment of the DX Office, public managers had already enabled several actions to address many of the challenges that emerged over the course of the project. The introduction of organizational measures allowed a better alignment among public managers. Discrepancies about the framing of technology had been limited in order to guarantee a shared understanding, sensemaking and enabling of technology instruments within the Ministry, as confirmed by interviewees C, D and E. These measures had an impact on the reorganization of administrative workflows, and they built the path towards the realization of a better public service provision.

However, despite the progress achieved, the three sub-projects which emerged from the workshops did not offer a comprehensive and unified source of information available for SMEs. In this final stage of the project, public managers pursued the unification of the three sub-projects as a solution to avoid decoupling and further fragmentation of information provision. It should be noted that while in Phase 1 public managers' concerns regarded the way by which different views of technology could hinder the process to the realization of an ICT-based policy, in Phase 3 they concentrated on the final interface to release. They focused on how the integration of the three sub-projects could improve the functionalities, usability and accessibility of the final web portal. In terms of values, they focused on the characteristics of the public service the Ministry aimed to deliver, which is an outward dimension.

Technological frames alignment played a crucial role in phase 3. Despite the fact that the three sub-projects were carried on separately, public managers came up with common solutions. As public managers E, C and D confirmed through the interviews, they shared the belief that only the integration of the interfaces could provide a meaningful public service. This alignment on the social construction of technology was built through several measures undertaken in Phases 1 and 2 (notably, the hearings process, the hiring of $\mathrm{C}$, and the workshops consultation). These measures allowed the public managers to intervene promptly: $\mathrm{C}$ managed to unify the three sub-projects, aiming to achieve the expected outcome. The technological frames which resulted in the construction of shared understanding of datasets and interfaces not only impacted on the interaction with the technology - three sub-projects were unified - but also provided a paramount contribution to the public value that managers prioritized in this phase of the project.

Figure 2 synthesizes the process by which technological frames impacted on the nature and on the relevance of different public values. 
Phase 1 - Start of the Project

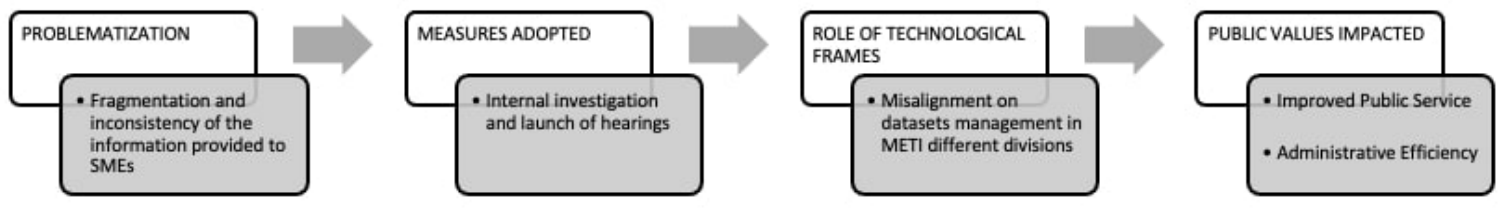

Phase 2 - Establishment of DX Office
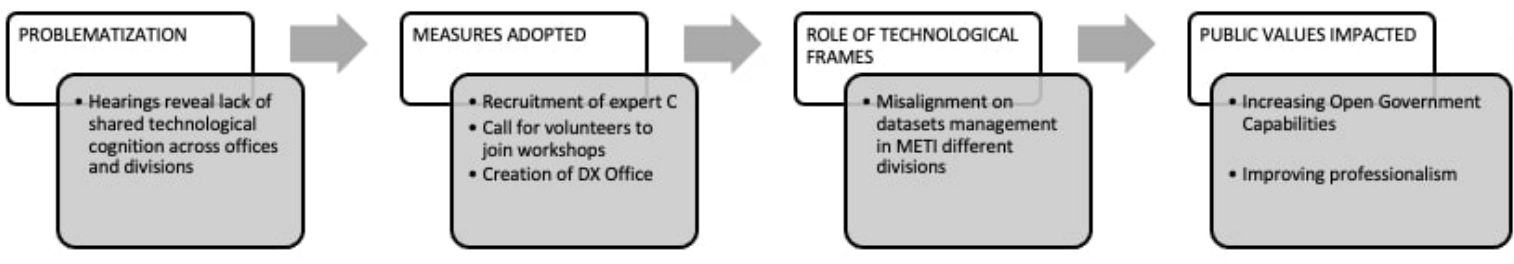

Phase 3 - Integration of the sub-projects
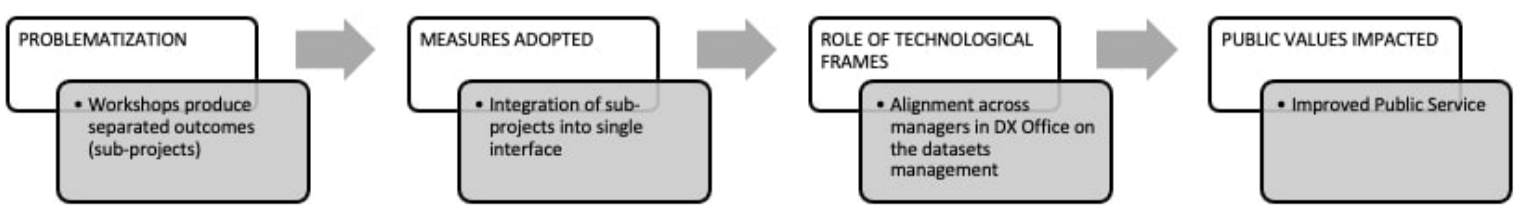

Figure 2. Problematization, Measure Adoption, and How Technological Frames Impacted on the Public Value Creation in the Project

\section{Conclusions}

The research aimed to shed a light on the way by which aligned or misaligned technological frames impact on the nature of the public values of an e-government project. We relied on the findings from a Japanese government web portal aiming to provide key information to SMEs. The selected case showed how public managers in charge of the execution of the project confronted with the absence of shared social construction of technology. Despite the efforts put in place to overcome existing fragmentation, public managers found it extremely hard to construct a collective and aligned view about how the specific technology (in this case, a single web portal based on multiple datasets) should work.

The findings from the case highlight that not only the technological frames had an impact on the project - whose launch was delayed several times - but, most importantly, they impacted on the public values. Divergences and convergences on the social construction of technology caused multiple changes of directions in the project. At the beginning of the project, the fundamental purpose was to improve a public service (the information provision for SMEs). The more public managers reflected and acted accordingly to the technological frames they encountered, the more they aimed to pursue additional values through the same project. Those public values were identified according to Twizeyimana and Andersson [17] taxonomy. The findings from the analysis show that public managers aimed to achieve both outward-focusing values (such as the improvement of service provision) and inward-focusing values (such as administrative efficiency, Open Government capabilities, improved professionalism).

Hence, we argue that in order to adequately capture the transformation of public values inscribed into an e-government project it is paramount to adopt a dynamic perspective. The way by which public managers make sense of technology is not immutable over the course of a project. On the contrary, the construction of an aligned approach towards the significance, adoption and management of technology is a factor that makes a difference in the process of designing and implementing an e-government project. Moreover, as this research has tried to demonstrate, alignment or misalignment over the use of technology might directly impact the public values that the public managers aim to achieve.

\section{ACKNOWLEDGMENTS}

One of the authors has been employed in METI since 2009, as of the time of interview in 2020. No sensitive or confidential information has been utilized or released through this research. The academic purpose of the interviews has been thoroughly clarified to interviewees during data collection.

\section{REFERENCES}

$<$ bib id="bib1" $><$ number $>[1]</$ number $>$ [1] Zhicheng Wang and Kun Tang. 2020. Combating COVID-19: health equity matters. Nature medicine 26,4 (2020), $458-458$. https://doi.org/10.1038/s41591-020-0823-6

$<$ bib id="bib2" $><$ number $>[2]<$ /number $>$ [2] Hasan Hashim, Angela Lin, and Jonathan Foster. 2016. Barriers surrounding e-government implementation: A case study of Government to Business (G2B) system. In International Conference on Communication, Management and Information Technology (Cosenza, Italy, 26-29 April 2016). 2016. CRC Press. $</$ bib $>$ 
$<$ bib id="bib3" $><$ number $>[3]<$ number $>$ [3] Ricardo Santa, Jason B. MacDonald, and Mario Ferrer. 2019. The role of trust in e-Government effectiveness, operational effectiveness and user satisfaction: Lessons from Saudi Arabia in e-G2B. Government Information Quarterly 36, 1 (2019), 39-50.

https://doi.org/10.1016/j.giq.2018.10.007 $\leq /$ bib $>$

$<$ bib id="bib4" $><$ number $>[4]<$ /number $>$ [4] Silas Formunyuy Verkijika and Lizette De Wet. 2018. Quality assessment of e-government websites in Sub-Saharan Africa: A public values perspective. The Electronic Journal of Information Systems in Developing Countries 84, 2 (2018), e12015. https://doi.org/10.1002/isd2.12015</bib $>$

$<$ bib id="bib5" $><$ number $>[5]<$ number $>$ [5] Naci Karkin and Marijn Janssen. 2014. Evaluating websites from a public value perspective: A review of Turkish local government websites. International Journal of Information Management 34, 3 (2014), 351-363. https://doi.org/10.1016/j.ijinfomgt.2013.11.004</bib $>$

$<$ bib id="bib6" $><$ number $>[6]</$ number $>$ [6] Mike Grimsley and Anthony Meehan. 2007. e-Government information systems: Evaluation-led design for public value and client trust. European Journal of Information Systems 16, 2 (2007), 134-148. https://doi.org/10.1057/palgrave.ejis.3000674</bib $>$

$<$ bib id="bib7" $><$ number $>[7]</$ number $>$ [7] Jeremy Rose, John Stouby Persson, Lise Tordrup Heeager, and Zahir Irani. 2015. Managing e-Government: value positions and relationships. Information Systems Journal 25, 5 (2015), 531-571. https://doi.org/10.1111/isj.12052</bib $>$

$<$ bib id="bib8" $><$ number $>[8]</$ number $>$ [8] Wanda J. Orlikowski and Debra C. Gash. 1994. Technological frames: making sense of information technology in organizations. ACM Transactions on Information Systems (TOIS) 12, 2 (1994), 174-207. https://doi.org/10.1145/196734.196745</bib $>$

$<$ bib id="bib9" $><$ number $>[9]</$ number $>$ [9] Wanda J. Orlikowski. 2000. Using technology and constituting structures: A practice lens for studying technology in organizations. Organization science 11, 4 (2000), 404-428. https://doi.org/10.1287/orsc.11.4.404.14600</bib $>$

$<$ bib id="bib10" $><$ number $>[10]<$ /number $>$ [10] Sarah Kaplan and Mary Tripsas. 2008. Thinking about technology: Applying a cognitive lens to technical change. Research Policy 37, 5 (2008), 790-805. https://doi.org/10.1016/j.respol.2008.02.002 $</$ bib $>$

$<$ bib id="bib11" $><$ number $>[11]<$ /number $>$ [11] Ali A. Guenduez, Tobias Mettler, and Kuno Schedler. 2020. Technological frames in public administration: What do public managers think of big data? Government Information Quarterly 37, 1 (2020), 101406. https://doi.org/10.1016/j.giq.2019.101406</bib $>$

$<$ bib id="bib12" $><$ number $>[12]<$ /number $>$ [12] Mark H. Moore. 1994. Public value as the focus of strategy. Australian Journal of Public Administration 53, 3 (1994), 296-303. https://search.informit.org/doi/10.3316/agispt.20025543.</bib $>$

$<$ bib id="bib13" $><$ number $>[13]</$ number $>$ [13] Mark H. Moore. 1995. Creating public value : strategic management in government. Cambridge, Mass.: Harvard University Press. $</$ bib $>$

$<$ bib id="bib14" $><$ number $>[14]<$ number $>$ [14] John Alford and Janine O'Flynn. 2009. Making sense of public value: Concepts, critiques and emergent meanings. International Journal of Public Administration 32, 3-4 (2009), 171-191. https://doi.org/10.1080/01900690902732731 </bib $>$

$<$ bib id="bib15" $><$ number $>[15]</$ number $>$ [15] Antonio Cordella and Carla M. Bonina. 2012. A public value perspective for ICT enabled public sector reforms: A theoretical reflection. Government Information Quarterly 29, 4 (2012), 512-520. https://doi.org/10.1016/j.giq.2012.03.004 $\leq /$ bib $>$

$<$ bib id="bib16" $><$ number $>[16]</$ number $>$ [16] John C. Bertot, Elsa Estevez, and Tomasz Janowski. 2016. Universal and contextualized public services: Digital public service innovation framework. Government Information Quarterly 33, 2 (2016), 211-222. DOI: 10.1016/j.giq.2016.05.004</bib $>$

$<$ bib id="bib17" $><$ number $>[17]</$ number $>$ [17] Jean Damascene Twizeyimana and Annika Andersson. 2019. The public value of E-Government-A literature review. Government Information Quarterly 36, 2 (2019), 167-178. https://doi.org/10.1016/j.giq.2019.01.001</bib $>$

$<$ bib id="bib18" $><$ number $>[18]<$ /number $>$ [18] Panos Panagiotopoulos, Bram Klievink, and Antonio Cordella. 2019. Public value creation in digital government. Government Information Quarterly 36, 4 (2019), 101421. https://doi.org/10.1016/j.giq.2019.101421.</bib>

$<$ bib id="bib19" $><$ number $>[19]<$ /number $>$ [19] Frank Bannister and Regina Connolly. 2014. ICT, public values and transformative government: A framework and programme for research. Government Information Quarterly 31, 1 (2014), 119-128. https://doi.org/10.1016/j.giq.2013.06.002</bib $>$

$<$ bib id="bib20" $><$ number $>[20]<$ number $>$ [20] Torben Beck Jørgensen and Barry Bozeman. 2007. Public values: An inventory. Administration \& society 39, 3 (2007), 354-381. https://doi.org/10.1177/0095399707300703 $</$ bib $>$

$<$ bib id="bib21" $><$ number $>[21]</$ number $>$ [21] Paul Davis and Karen West. 2009. What do public values mean for public action? Putting public values in their plural place. The American Review of Public Administration 39, 6 (2009), 602-618. https://doi.org/10.1177/0275074008328499 </bib $>$

$<$ bib id="bib22" $><$ number $>[22]<$ /number $>$ [22] Alberto Savoldelli, Gianluca Misuraca, and Cristiano Codagnone. 2013. Measuring the Public value of e-Government The eGEP2. 0 model. Electronic Journal of e-Government 11, 1 (2013), 373-388. $<$ /bib $>$

$<$ bib id="bib23" $><$ number $>[23]<$ number $>$ [23] Jean Hartley, John Alford, Eva Knies, and Scott Douglas. 2017. Towards an empirical research agenda for public value theory. Public Management Review 19, 5 (2017), 670-685. https://doi.org/10.1080/14719037.2016.1192166 </bib $>$

$<$ bib id="bib24" $><$ number $>[24]</$ number $>$ [24] Min-Seok Pang, Gwanhoo Lee, and William H DeLone. 2014. IT resources, organizational capabilities, and value creation in public-sector organizations: a public-value management perspective. Journal of Information Technology 29, 3 (2014), 187-205. https://doi.org/10.1057/jit.2014.2</bib $>$ $<$ bib id="bib25" $><$ number $>[25]<$ /number $>$ [25] Barry Bozeman. 2007. Public values and public interest: Counterbalancing economic individualism. Georgetown

University Press. $</$ bib $>$

$<$ bib id="bib26" $><$ number $>[26]</$ number $>$ [26] Antonio Cordella and Andrea Paletti. 2019. Government as a platform, orchestration, and public value creation: The Italian case. Government Information Quarterly 36, 4 (2019), 101409. https://doi.org/10.1016/j.giq.2019.101409</bib $>$

$<$ bib id="bib27" $><$ number $>[27]<$ number $>$ [27] Tony Bovaird. 2007. Beyond engagement and participation: User and community coproduction of public services. Public Administration Review 67, 5 (2007), 846-860. https://doi.org/10.1111/j.1540-6210.2007.00773.x $<$ /bib $>$

$<$ bib id="bib28" $><$ number $>[28]</$ number $>$ [28] Virginia Acha, Technology frames: The art of perspective and interpretation in strategy. 2004, SPRU-Science Policy Research Unit, University of Sussex Business School. $<$ bib $>$

$<$ bib id="bib29" $><$ number $>[29]</$ number $>$ [29] Paul M. Leonardi. 2011. Innovation blindness: Culture, frames, and cross-boundary problem construction in the development of new technology concepts. Organization Science 22, 2 (2011), 347-369. https://doi.org/10.1287/orsc.1100.0529</bib >

$<$ bib id="bib30" $><$ number $>[30]</$ number $>$ [30] Paul M. Leonardi and Stephen R. Barley. 2010. What's under construction here? Social action, materiality, and power in constructivist studies of technology and organizing. Academy of Management Annals 4, 1 (2010), 1-51. https://doi.org/10.5465/19416521003654160 $\leq /$ bib $>$ $<$ bib id="bib31" $><$ number $>[31]</$ number $>$ [31] Abhay Nath Mishra and Ritu Agarwal. 2010. Technological frames, organizational capabilities, and IT use: An empirical investigation of electronic procurement. Information Systems Research 21, 2 (2010), 249-270. https://doi.org/10.1287/isre.1080.0220</bib $>$

$<$ bib id="bib32" $><$ number $>[32]</$ number $>$ [32] Paul M. Leonardi. 2007. Activating the informational capabilities of information technology for organizational change. Organization science 18,5 (2007), 813-831. https://doi.org/10.1287/orsc. $1070.0284</$ bib $>$

$<$ bib id="bib33" $><$ number $>[33]<$ /number $>$ [33] Fariborz Damanpour and Marguerite Schneider. 2009. Characteristics of innovation and innovation adoption in public organizations: Assessing the role of managers. Journal of Public Administration Research and Theory 19, 3 (2009), 495-522. https://doi.org/10.1093/jopart/mun021</bib $>$ $<$ bib id="bib34" $><$ number $>[34]</$ number $>$ [34] Tina Nabatchi. 2018. Public values frames in administration and governance. Perspectives on Public Management and Governance 1, 1 (2018), 59-72. https://doi.org/10.1093/ppmgov/gvx009</bib $>$

$<$ bib id="bib35" $><$ number $>[35]</$ number $>$ [35] Montgomery Van Wart. 1998. Changing public sector values. 1st ed. New York: Routledge. $</$ bib $>$

$<$ bib id="bib36" $><$ number $>[36]</$ number $>$ [36] Valentina Ndou. 2004. E-Government for developing countries: opportunities and challenges. The Electronic Journal of Information Systems in Developing Countries 18, 1 (2004), 1-24. </bib $>$

$<$ bib id="bib37" $><$ number $>[37]<$ /number $>$ [37] Kathleen M Eisenhardt. 1989. Theory building from case study research. Academy of Management Review 14, 4 (1989), 532-550. https://doi.org/10.5465/amr.1989.4308385</bib $>$

$<$ bib id="bib38" $><$ number $>[38]</$ number $>$ [38] Robert K. Yin. 2018. Case study research and applications : design and methods. Sixth edition. ed. Los Angeles: SAGE. $<$ bib $>$

$<$ bib id="bib39" $><$ number $>[39]<$ /number $>$ [39] Allen S. Lee and Richard L. Baskerville. 2003. Generalizing generalizability in information systems research. Information Systems Research 14, 3 (2003), 221-243. DOI: 10.1287/isre.14.3.221.16560</bib $>$

$<$ bib id="bib40" $><$ number $>[40]</$ number $>$ [40] Kuniyoshi Saito and Daisuke Tsuruta. 2018. Information asymmetry in small and medium enterprise credit guarantee schemes: evidence from Japan. Applied Economics 50, 22 (2018), 2469-2485. https://doi.org/10.1080/00036846.2017.1400651</bib $>$

$<$ bib id="bib41"><number $>[41]</$ number $>$ [41] METI. 2013. We will open 'Mirasapo', a site that supports the future of SMEs and small businesses (中小企業・小規模 事業者の未来をサポートするサイト「ミラサポ」を開設します). 31/07/2013.

https://warp.da.ndl.go.jp/info:ndljp/pid/8262539/www.meti.go.jp/press/2013/07/20130730003/20130730003.html.</bib> 